NBER WORKING PAPER SERIES

\title{
UNDERSTANDING CROSS-NATIONAL TRENDS IN HIGH-TECH RENEWABLE POWER EQUIPMENT EXPORTS TO THE UNITED STATES
}

\author{
Aparna Sawhney \\ Matthew E. Kahn \\ Working Paper 17217 \\ http://www.nber.org/papers/w17217
NATIONAL BUREAU OF ECONOMIC RESEARCH
1050 Massachusetts Avenue
Cambridge, MA 02138
July 2011

This paper was written while Sawhney was a Visiting Scholar at the UCLA Institute of Environment and the Luskin Center for Innovation. We thank the Luskin Center for research support. The views expressed herein are those of the authors and do not necessarily reflect the views of the National Bureau of Economic Research.

NBER working papers are circulated for discussion and comment purposes. They have not been peerreviewed or been subject to the review by the NBER Board of Directors that accompanies official NBER publications.

(C) 2011 by Aparna Sawhney and Matthew E. Kahn. All rights reserved. Short sections of text, not to exceed two paragraphs, may be quoted without explicit permission provided that full credit, including (C) notice, is given to the source. 
Understanding Cross-National Trends in High-Tech Renewable Power Equipment Exports to the United States

Aparna Sawhney and Matthew E. Kahn

NBER Working Paper No. 17217

July 2011

JEL No. F14,Q55,Q56

\begin{abstract}
We track US imports of advanced technology wind and solar power-generation equipment from a panel of countries during 1989-2010, and examine the determining factors including sector-specific US FDI outflow, country size, and domestic wind and solar power generation. Differentiating between the core high-tech and the balance of system equipment, we find US imports of the both categories have grown at significantly higher rate from the relatively poorer countries, particularly China and India. US FDI is found to play a significant positive role in the exports of high-tech equipment from both rich and poor countries, especially for the balance of system equipment. For the core wind and solar equipment, we find domestic renewable power generation played a significant positive role, and the effect is more pronounced for the rich countries as well as China compared to other poor countries.
\end{abstract}

Aparna Sawhney

Centre for International Trade and Development

Jawaharlal Nehru University

New Delhi 110067

asawhney@mail.jnu.ac.in

Matthew E. Kahn

UCLA Institute of the Environment

Department of Economics

Department of Public Policy

Box 951496

La Kretz Hall, Suite 300

Los Angeles, CA 90095-1496

and NBER

mkahn@ioe.ucla.edu 


\section{Introduction}

World demand for electricity is rising, especially in the developing world. If fossil fuel fired power plants that rely on coal or natural gas continue to grow in nations such as China and India, then global greenhouse gas emissions will accelerate and the damage caused by climate change will be even worse. To slowdown potentially catastrophic impacts of climate change will require increasing reliance on (renewable) wind and solar power to generate electricity. Today, there is an ongoing debate about the economic feasibility of these nascent technologies. Optimists foresee large learning by doing effects as average cost declines with cumulative experience (Duke and Kammen 1999). Pessimists point to the large subsidies these industries receive and argue that purely based on power generated per dollar invested that the returns are quite low (Lesser 2010).

Global international trade is likely to play an important role in accelerating innovation and cost reduction in green technology. We examine exports of advanced technology renewable energy equipment based on a panel of developed and developing countries during the years 1989 to 2010, a period marked by liberalization and rising FDI in developing countries, particularly China and India. ${ }^{2}$ Inward foreign direct investment brings clean technology when multinational firms set up equipment production or build energy systems. We choose the US import market, since the US ranks among the leading nations in terms of both cutting-edge technologies in the field as well as trade and size of the domestic market; thus, products entering the market require qualityconformity. We find that developing countries have eroded the developed countries' shares in the US import market during the last two decades. For instance China now commands almost half the US import market of solar modules by value, while India's share in wind turbines and blades is more than $10 \%$.

There is a certain irony that trade with developing countries is accelerating the development of the "green economy". The trade and environment literature has studied the conditions such that

\footnotetext{
${ }^{2}$ China and India implemented major economic reforms in 1991-92.
} 
poor nations would be pollution havens for rich countries as dirty factories could escape tight regulation in rich countries by re-locating to poorer nations (Copeland and Taylor 2003, 2004). This literature emphasizes that the location of dirty economic activity will be determined by both factor endowments and regulatory intensity.

In the case of "green energy" trade, the poorer South is emerging as a key provider of cheap equipment for renewable-power generation to the rich North for its production and consumption of clean energy. If clean energy prices decline then they are more likely to induce a composition shift as nations choose to substitute them for fossil fuel generated electricity (i.e coal and natural gas). Such a composition shift could significantly reduce national greenhouse gas emissions associated with power generation.

The leading sources of renewable energy technology in the world today, especially in wind and solar technology, are the industrialized countries of Germany, Japan, United States and Denmark - where cutting-edge technology is rapidly evolving as evident in their vigorous patenting activity. ${ }^{3}$ Among the different renewable energy forms, wind and solar have been the fastest growing power-generation technologies in the last twenty years, with the largest grid-connected installed capacities in countries like the US, China, Germany, Italy, Japan, Spain and India in wind and solar photovoltaic (REN21 2010). The growth of the renewable power-generation sector has taken place with policy support in all the countries, and with foreign technology-dependence in the emerging economies. Technology transfer is seen as an efficient means to mitigate global warming, whereby developing countries which are yet to indigenously develop such technology can leap-frog onto a cleaner growth path.

In examining US imports of wind and solar power generation equipment, we distinguish between imports from relatively rich and poor countries, and then compare the trend growth of China and India against the benchmark of these country groups. We test whether sector-specific US

\footnotetext{
${ }^{3}$ Overall solar and wind power and hydrogen and fuel cell technologies have witnessed the most substantial increases in patent applications, both in terms of numbers and shares in total alternative energy filings at the European Patent Office and through the Patent Cooperative Treaty (WIPO, 2009).
} 
FDI and home market size (size of the economy and size of renewable electricity) can explain the observed time trends. We find that US sector-specific FDI has been a significant determinant of export growth from rich and poor countries, especially for balance of system high-tech powergeneration equipment, while domestic renewable power generation played a significant role in the export of core high-tech wind and solar equipment.

Our paper contributes to the growing literature on international technology transfer related to climate change mitigation from the developed to the developing countries (Popp et al 2009, Driesen and Popp 2010). ${ }^{4}$ Here we consider growing wind-solar power equipment exports to the US as an indicator of clean technology diffusion following inward FDI from the US and domestic wind-solar power generation.

The rest of the paper is organized as follows: Section 2 gives the theoretical and analytical background; as well as a brief description of the US imports of wind and solar high-tech power generation equipment during the last two decades; Section 3 outlines the hypotheses and the basic regression specification; Section 4 summarizes the series of regression results; and Section 5 concludes.

\section{Theoretical Background}

The trade literature predicts that with technology transfer, developing countries will emerge as exporters of the older products while the North moves into further higher technology through continuous innovation - leading to the product cycle pattern of trade. Vernon had observed that the product cycle is evident for industries like chemicals, electronics, machinery, and transportation

\footnotetext{
${ }^{4}$ Much of the focus has been on Clean Development Mechanism (CDM) projects where technology diffusion has occurred without policy prescriptions, being driven instead by firms seeking to lower production costs (Popp 2011). Inter-country CDM comparisons show that strong economic growth and domestic technological capabilities have been important for countries like China and India, while involvement of foreign partners have been more important for countries like Brazil and Mexico (Dechezleprete et al 2009).
} 
equipment sectors, where he noted innovations were prominent (Vernon 1979: 258). ${ }^{5}$ Indeed, most of the high-technology renewable equipment that we examine here are in the electronics and machinery sectors.

North-South trade in high-technology products can be explained using product cycle models (Vernon 1966, Krugman 1979, Flam and Helpman 1987, Grossman and Helpman 1989), where the developing South emerges as the exporter of older technology products and the North moves into further higher quality exports driven by their innovation. North-North trade in high-technology products, on the other hand, is driven by particular technological differences (Posner 1961), product differentiation, economies of scale and home market effect (Krugman 1980).

Recent trade empirics have focussed on the phenomenal surge of sophisticated imports in OECD countries from the South, especially countries like China and India. Disaggregated analyses find that within the same product classification at 10-digit US HTS, US imports from developing countries exhibit lower prices (hence lower quality) compared to those from developed countries (Schott 2004, 2008), indicating that the North continues to export higher quality verticallydifferentiated products compared to the South. This suggests that based on intrinsic quality difference of the final products, the imports from developed versus developing countries within the US market are imperfect substitutes (if at all).

The lower quality notwithstanding, competition from Chinese imports has stimulated further innovation and patent activity among Western European firms in a bid to survive and increase profits (Bloom et al 2011). Their work gives evidence of technological up-gradation in industries of Western Europe most affected by Chinese imports (at 6 digit HS) - through innovation and patenting among surviving firms in the industrialized countries. The result is robust even after controlling for product-switching and outsourcing by the OECD firms, which suggests that technological quality of imports from an emerging country like China does pose a credible threat to

\footnotetext{
${ }^{5}$ Indeed FDI tends to be greater in technically progressive industries, and multinational firms are concentrated in industries with higher share of R\&D to sales (Saggi 2002).
} 
existing high-technology industries pushing them to innovate further, and affirms the essence of the product-cycle theory. ${ }^{6}$

International investment is the key channel of technology transfer to the developing South in the product-cycle theory (Vernon 1966). Extensions of the product-cycle trade model with sectorspecific capital mobility show that the range of higher quality exports from the South increase with FDI (Falvey 1981, Grossman and Helpman 1989). ${ }^{7}$ Inward FDI in developing countries introduces new industries in these countries, and promotes exports to the home countries of multinational affiliates with the advantage of market networks (Lipsey 2004, 2000, Liu et al 2001). ${ }^{8}$

Another channel of technology transfer for developing countries can be the import of goods, especially intermediate goods that embody high technology. ${ }^{9}$ The increasing sophistication of exports of developing countries is a reflection of the underlying sophisticated imported components before assembly and re-exports (Krugman 2008). Indeed as Hummels et al (2001) demonstrated, processing trade has grown in world trade in general, and developing countries play a significant role in the production chain spanning several countries (termed vertical specialization). Here too FDI has played an important role since multinationals are largely involved in processing trade, and outsource to developing countries to benefit from lower labour costs. For example, foreign invested firms dominate in China's high-technology exports (Xing 2011), and foreign-content in exports is

\footnotetext{
${ }^{6}$ The product cycle hypothesis assumes that the stimulus to innovation is typically provided by some threat or promise in the market, and firms being "acutely myopic" are stimulated by conditions in the closest market, namely the home market (Vernon 1979).

${ }^{7}$ Models differ in terms of whether R\&D is exogenous or endogenous. Foreign direct investment in developing countries lead to productivity gains following technology diffusion, where the rate of diffusion depends on features of the backward economy including relative capital stock, education level of the labour force, and terms of licensing arrangements (Findlay 1978: 5). The extent of benefits from FDI eventually depend on the host country facilitating factors of domestic physical and knowledge capital, as well as policy regime. The efficacy of inward FDI (as well as its volume) will be higher in a developing country with export-promotion policy regime compared to a country with import-substitution, ceteris paribus (Bhagwati 1978).

${ }^{8}$ The literature indicates that the export growth effect of FDI in the host country can hold not only when FDI is efficiency-seeking (re-location of production due to cost advantage in the host country), but even when FDI is marketseeking (i.e. production to serve host country market) - since domestic firms of the host country benefit from market network linkage of the foreign affiliates.

${ }^{9}$ To the extent non-codified knowledge may be more readily transferred through greater personal contact, FDI and interaction with multinationals raise the probability of international R\&D spillovers. See Keller (2004) for an excellent review on international technology diffusion.
} 
higher from foreign invested firms (Koopman et al 2008). ${ }^{10}$ Higher imports of intermediate products also help in product innovation for domestic firms as established in the case of India (Goldberg et al 2010).

In developed countries too, FDI plays an important role in technology diffusion. FDI among European countries was found to be significant effect on technical progress, export and economic growth (Barrell and Pain, 1997). Alfaro et al (2009) showed that large part of FDI among developed countries is efficiency-seeking "vertical" in nature, and multinationals are relocating high-skill intra-industry production to other developed countries.

\subsection{US Imports of Wind and Solar Power Generation Equipment}

For our analysis of US imports of wind and solar power generation equipment, we identify a total of 27 products at 10-digit HTS codes based on energy equipment mapping of the USITC and ICTSD (see Table A1 at the end for details of concordance with renewable energy components). ${ }^{11}$ The selected equipment in our analysis is a subset the list of environmental goods being negotiated under the Doha Round of the current WTO negotiations. ${ }^{12}$ We classify five of these products as core high-technology equipment and 22 products as balance of system equipment. Among our core high-technology equipment, wind turbine is final product, while blade and hub are components of wind turbines, and solar photovoltaic cells are components of solar modules. The balance of system equipment also includes high-technology components (like anemometer, clutch, gearbox, rectifier, etc.). All the equipment are components of the overall power generation system.

\footnotetext{
${ }^{10}$ With government policy facilitating outsourcing and processing trade in China.

${ }^{11}$ Harmonized commodity description and coding system for tariff or HTS is maintained by the World Customs Organization and used world-wide for classifying traded commodities. While codes up to 6-digits are set internationally, individual countries are allowed to assign additional 2 or 4 digits for additional subcategories. ${ }^{12}$ In the Doha negotiations, the environmental goods are specified at 6 digit-HS 2002 codes. The equipment analyzed in our paper correspond to thirteen of these products under negotiation namely $730820,841290,848340,848360$, 850161, 850162, 850163, 850164, 850231, 850300, 850440, 854140, and 902680 (Annex IIA of WTO (2011). Since our 27 products are at a more disaggregated level of 10-digit US HS codes, several disaggregated products often correspond to a single 6-digit good.
} 
In selecting the products we will study, we exclude other components such as glass, lead-acid batteries, wires, switches, etc, since at the 10-digit HTS classification it is difficult to delineate the high-quality products which would be utilized in the wind/ solar power generation system. More importantly, it allows us to minimize the inclusion of multiple-use balance of system equipment that are imported for purposes other than renewable electricity generation; and also preclude products where innovation is not high. The total value of US import (from the rest of the world) of the selected wind and solar equipment increased from US\$0.8 billion in 1989 to US\$9.4billion in 2010 (constant 2000\$), with a higher growth in the core high-tech equipment (see Table 1).

Our choice of 24 countries covers a diverse range of developed and emerging countries exporting the subset of products covered here. These countries together accounted for more than $90 \%$ of US imports by value in each of the twenty-seven 10-digit HTS products for most of the years during the period considered. The country shares in the US import of the core high-tech products in 1989 versus 2010 are depicted in Table 2.

The share of China in US imports of core wind and solar energy equipment, including solar panels/module, and blades have steadily increased, while Japan, Germany, United Kingdom have experienced a substantial erosion in their shares in the US market. India, on the other hand, experienced a more significant growth in wind turbines. While there has been drastic loss of market share in the US among the erstwhile leading nations like Denmark, Germany, Japan, United Kingdom, they continue to maintain dominant shares (and in the case of wind-turbines there is a remarkable reversal of Denmark's trend beginning 2008) - reflecting the lead in innovating and high-value products from these countries.

\subsection{US FDI outflow in the selected manufacturing sectors, 1988-2009}


The US remains a leading source of outward-FDI in the world (UNCTAD 2010), and for emerging countries like China and India as well. ${ }^{13}$ Since we are interested in tracking the significance of US FDI in the US import of the green energy equipment, we track the investment outflows in four manufacturing sectors. ${ }^{14}$

The annual sector-specific US FDI outflows across countries provide insights on how the pattern of investment has changed in the last two decades. For a cross-country time-series analysis, the data on sector-specific US FDI is available only at the 3-digit NAICS (and SIC 2-digit prior to 1999) from US Bureau of Economic Analysis. ${ }^{15}$ Thus our analysis here pertains to horizontal FDI, and does not distinguish the portion of vertical FDI within these industries (that would be evident at higher disaggregation of 4-digit SIC). The equipment imports associated with wind and solar power generation come from four manufacturing sectors: primary and fabricated metal (NAICS 331 and 332), machine manufacturing (NAICS 333), electrical equipment (NAICS 335), and computer and electronic products (NAICS 334). ${ }^{16}$

Considering the US FDI outflows in these four sectors, the largest recipients continue to be the countries like Canada, Germany, and United Kingdom throughout the period of analysis. While Japan and Italy were among the high recipients in the initial years, they have receded in their ranks. Among the relatively poorer nations Brazil, Malaysia, Mexico, Singapore, Taiwan are among the high recipients of FDI in these manufacturing sectors. While both China and India were among the low recipients among the twenty-four countries considered, the US FDI flows to China have increased steadily. China now is among the top recipients of US FDI in these four sectors

\footnotetext{
${ }^{13}$ Although for China, countries like Hong Kong and Taiwan appear to be the major FDI sources much of this is based on "round-tripping" for tax, financial and other institutional advantages. Similarly for India, Mauritius has long been documented as the largest source of FDI, even though it is due to the routing based on incentive to evade taxes.

${ }^{14}$ Of course US imports of high-technology power equipment from a country are also affected by FDI inflow into the latter from a third country. However, the time-series data on FDI-inflows, classified by the four manufacturing sectors used here, is not available for all countries.

${ }^{15}$ However, some of the US FDI data by country and industry level are withheld to avoid disclosure of data of certain companies, thus leading to missing data for those years.

${ }^{16}$ US BEA reports the sector of computer and electronic products separately beginning 1999 . For the period 1988-1998, FDI is reported together with the sector of electrical equipment. Thus for continuity in our sector-wise analysis, we consider the FDI in electrical equipment also to be the FDI for electronic products for the years 1988 through 1998.
} 
(especially since 2007). The figure below shows that actual US FDI outflows (in constant US\$) in the four manufacturing sectors to China and India as well as the highest recipient countries in our panel.

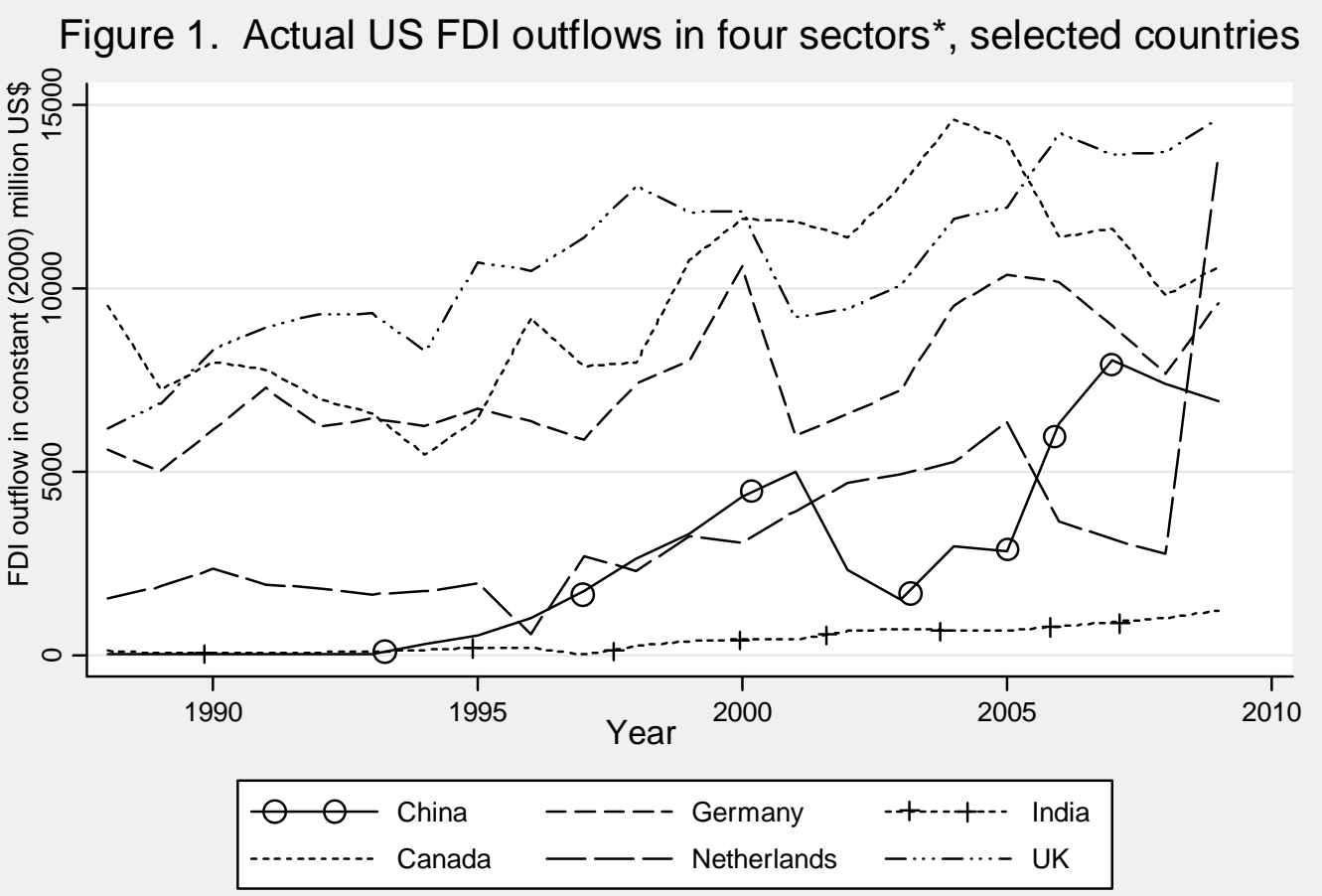

* Covers the four sectors of primary/fabricated metal, machinery, electrical and electronic equipment.

A sector-wise distribution and pattern of US FDI abroad in the twenty-four countries during 1988-2009, indicates that, on the whole, US FDI outflow in the computer and electronic products witnessed the highest annual growth followed by metal and fabricated metal. ${ }^{17}$ This pattern is true in both rich and poor countries. The only difference, however, is that US FDI outflow in machine manufacturing to the rich countries show a negative trend, but has been growing in the poor countries.

\footnotetext{
${ }^{17}$ The decline in electrical sector occurs due to re-classification of computer and electronic products as a separate sector beginning 1999.
} 


\subsection{Model Specification}

In order to estimate our trade regressions, we have merged together several different data sets. The US import data is taken from Robert Feenstra's trade database (1989-2006), and supplemented with data from the USITC online database for years 2007 through 2010. The US FDI data is taken from US Bureau of Economic Analysis. Price indices for deflation of import data and FDI are taken from US Bureau of Labour Statistics. Country-specific data on GDP and electricity from wind-solar-biomass-geothermal are from the IMF and World Bank database (see the Data appendix for details).

With products defined at the 10-digit US HTS code, our regression covers the components of wind- and solar-based power generation systems (but some like the wind-powered generator or solar photovoltaic panel and module are final products that are connected to other balance of system equipment). Our basic pooled regression model with country fixed-effects is given by the equation (1) below.

$$
\begin{aligned}
& \log \left(\text { Import }_{i j t}^{u s}\right)=\alpha_{j}+\text { Dummy }_{c}+\text { Dummy }_{m}+\beta . \text { Group } * t+\beta \text {.Core } * \text { Group } * t+\beta . \text { India } * \\
& \text { Core } * t+\beta \text {.China } * \text { Core } * t+\gamma \cdot \log \left(F D I_{m, j, t-1}\right)+\delta \log \left(G D P_{j, t-1}\right)+ \\
& \mu \cdot \log \left(\text { RenewElec }_{j, t-1}\right) * \text { Core }+\epsilon_{i j t}, \quad i=1, ., 27 \text { products } \in \text { Category }= \\
& \text { Core/NonCore } ; j=1, \ldots 24 \text { countries } \in \text { Group }=\text { Rich/Poor }
\end{aligned}
$$

Where,

Import $_{i j t}{ }^{\text {us }}=\mathrm{US}$ import of product $i$ from country $j$ in year $t, t=1989$ to 2010;

Dummy $_{c}=$ dummy for core high-tech product

Dummy $y_{m}=$ dummy for manufacturing sector $m$ in which product $i$ is manufactured, whether

primary/ fabricated metal; machine manufacturing; electrical equipment; electronic products (at 3digit NAICS)

Category= category of the products or equipment: core and balance of system

Group $=$ group classification of country $j$, whether relatively poor or rich . 
$F D I_{m j}$, $=$ US foreign direct investment in manufacturing sector $m$ (which produces equipment $i$ ) in country $j$,

$G D P=$ gross domestic product in constant US dollars, used as the proxy for economic size

RenewElec $_{j}=$ renewable electricity production (from wind, solar, geothermal \& biomass) in country

$j$.

Since we want to compare the export growth rates of China and India against the benchmark of the two groups of country, we have dummies for China and India in trend interactions. We also have a dummy for the product category (core vs balance of system equipment) and a dummy for the industrial sector to which the product belongs (fabricated metal, machinery, electrical or electronic equipment). The determining variables appear with a lag of one year, to allow for the time to translate its impact through capital formation, production and finally export. Thus, each of the variables, namely US FDI in specific manufacturing sector (to which the export product belongs), total domestic output (GDP), and domestic renewable power generation appear with a time lag. Our country-fixed effects controls for other country-specific determinants of high-technology export growth like skilled labour force and government policy, which have not been included.

In our regressions, we control for country group-level, category of product (core high-tech equipment and balance of system equipment) and cluster by country and year. The US FDI is matched with the industrial classification (at 2 digit SIC / 3 digit NAICS) of the product being exported to the US (10 digit HTS code) to better reflect industry-specific impact in the host country. To control for the countries, we classify our panel of 24 countries into two groups of rich and poor, using the median real GDP per capita of the panel of countries in 1989 as the dividing line. ${ }^{18}$

\subsection{Hypotheses}

\footnotetext{
${ }^{18}$ The rich countries include Australia, Canada, Denmark, France, Germany, Hong Kong, Italy, Japan, Netherlands, Sweden, Switzerland, and United Kingdom. The second group of countries below the median income (we call relatively poor countries) includes Brazil, China, India, Indonesia, South Korea, Malaysia, Mexico, Philippines, Singapore, Spain, Taiwan, and Thailand.
} 
By estimating equation (1), we test three main hypotheses;

H1: Sector-specific US FDI elasticity of high-tech power generation equipment exports is positive.

H2: $\quad$ Larger home market size leads to higher high-tech power-generation equipment exports.

H3: Home market effect in terms of wind-solar power is positive for the core hightechnology renewable power generation equipment.

Following the FDI-trade literature, we expect US FDI to be an important determinant of exports of technology- and skill-intensive goods for both developed and developing countries. Empirics have shown that FDI flows serve as an important channel of technology diffusion, export and economic growth in the host countries (Barrel and Pain 1997, Blomstrom and Kokko 1997, Borensztein et al 1998). More recently, Buckley et al (2007 and 2002) found that higher FDI in China increased the development of new manufactures, and enhanced export intensities of domestic firms as well as foreign affiliates. ${ }^{19}$ Today FDI (in the industrial sector) is considered to be the largest source of private, climate-mitigation relevant financial flows from developed to developing countries (OECD 2009). Our hypothesis H1 provides a test of the export performance of developing countries in technologically sophisticated equipment to the US as an outcome of technology up-gradation largely as a result of sector-specific US FDI growth to these countries through the last two decades, against the benchmark of richer industrialized countries. ${ }^{20}$

Large countries tend to be large net exporters of goods in monopolistic competitive market setup (Krugman 1980), and there this home market effect is stronger in industries with more differentiated products and high transport cost (Hanson and Xiang 2004). The hypothesis H2 here tests whether countries with larger income are able to export larger amounts of the high-tech manufactured equipment to the US (after controlling for country fixed effects, and inward-FDI).

\footnotetext{
${ }^{19}$ The mechanism of technology diffusion work through backward and/or forward linkages of the operations of foreign affiliates in the host country, and becomes evident in plant-level productivity growth and FDI literature (Saggi 2002, Keller 2004).

${ }^{20}$ We expect that sector-specific FDI from third countries would positively affect home-country exports to the US. The omission of sector-specific FDI inflows from third countries, would give an upward bias to the estimated elasticity coefficient of US FDI.
} 
The period of our analysis also marks the take-off period in the long-term diffusion of wind turbine and solar cell technologies ${ }^{21}$. During the last two decades, the global solar and wind industry grew rapidly. The highest installed capacity of renewable energy, in particular of wind power and solar PV, is the region of European Union followed by the US and Japan, due to the strong government policy initiatives (in 2005 the EU accounted for $74 \%$ of the global wind power production, WIPO 2009: 28). A growing market for grid-tied wind and solar PV has also emerged in China and India (REN 2010). In China, domestic manufacturing of wind turbines and components has matured through the years and some are optimistic enough to claim that wind power can become competitive with coal-generated power by 2015-2020 (Yu et al 2009). ${ }^{22}$ Under H3, we test the significance of the growth of wind- and solar- electricity in the home countries (and the underlying policy promotion for renewable energy) in the export of such power-generating equipment to the US.

\section{Empirical Results}

Table 3 presents the regression results. As the data on the explanatory variables is incomplete (due to Taiwan and Singapore) for our entire panel of countries (and years), we run our regressions (and test the hypotheses) in a staggered manner as we include additional explanatory variables that are not available for all countries. ${ }^{23}$ Regressions 1 through 4 cover all 24 countries, while regressions 5-6 cover 22 countries.

Based on the results reported in columns (1-4), we find that the time trend growth in core hightech equipment exports from the rich countries is substantially higher $(10.26 \%$ per year $)$ than that in

\footnotetext{
${ }^{21}$ According to Jacobson and Lauber (2006) the take-off period of such tech-diffusion began in the 1990s.

${ }^{22}$ At the same time that China is ramping up its renewable power generation, $81 \%$ of China's power is generated using coal. China is sharply increasing its imports of coal and this has raised international coal prices. An unintended consequence of this is to nudge other nations to substitute away from coal to cleaner fuels (Wolak and Morse 2010). Today, wind provides only a small share of China's total electricity. For details see http://www.esi.nus.edu.sg/portal/Portals/0/18032011/China_He_Gang.pdf.

${ }^{23}$ Taiwan and Singapore are not included in regressions 5-6. Taiwan gets dropped since data on renewable electricity generation is missing, while Singapore gets dropped since the computed renewable power generation from wind/solar is zero. Since both Taiwan and Singapore are in the category of poor, our benchmark with poor countries changes in these regressions compared to the benchmark of poor country results reported in columns 1-4.
} 
the balance of system equipment (5.56\% per year). The poor countries experienced a higher trend growth rate than the rich countries in both categories of equipment (14.58\% and $9.88 \%$ per year in core and balance of system equipment, respectively). Thus, rich and poor nations enjoyed a faster trend growth in the core high-tech renewable power generation equipment than the non-core hightech equipment (Column 1).

Controlling for the US FDI in specific manufacturing sector and home market size (real GDP), we find that the trend growth rates reduce substantially for both groups of countries and product categories. In the rich countries, trend growth rates dropped to $3.2 \%$ and $7.38 \%$ per year in the balance of system and core high-tech equipment respectively (representing declines of $42 \%$ and $29 \%$ respectively). Similarly, for the poor countries the trend growth rates dropped to $5.26 \%$ per year and $12.64 \%$ per year in balance of system and core high-tech equipment, respectively (reductions of about $47 \%$ and $13.3 \%$, respectively). The sector-specific US FDI inflows and GDP are found to be highly significant with elasticity of export at 0.379 and 0.802 respectively (Column 2).

In regressions 3 of Table 3, we separate out the trend growth rates of China and India. We find that the rest of the poor countries now show lower trend growth rates for both balance of system as well as core high-tech equipment of $7.39 \%$ and $12.03 \%$ per year, respectively (in Column 3 compared to Column 1). However, the trend growth in exports from the poor countries continues to be significantly higher than that of the rich countries (column 3). Both China and India experienced substantially higher trend growth rates than the rich and poor countries; however, there is asymmetry in their growth dynamics. ${ }^{24}$ China exhibits a much higher trend growth than India in the balance of system equipment (24.75\% compared to $16.66 \%$ per year), while India exhibits a higher trend growth than China in the core balance of system equipment $(34.79 \%$ compared to 29.39\% per year). Controlling for FDI and real GDP (regression column 4), we again find that the

\footnotetext{
${ }^{24}$ The significantly higher trend growth of US imports in high-tech wind and solar power equipment from the poor countries (and particularly China and India) compared to rich developed countries holds true even when we measure imports relative to the total imports from these countries. These results are available on request.
} 
trend growth rates decline significantly for all countries and for both categories of equipment.

Moreover, the drop in the trend growth is relatively larger in the balance of system equipment than in the core high-tech equipment (comparing column 4 with column 3). In particular, the trend growth rates of Chinese exports reduced from $24.75 \%$ to $15.83 \%$ per year in the balance of system equipment and from $25.39 \%$ to $20.06 \%$ per year in the core high-tech equipment. For India, the trend growth rates dropped from $16.66 \%$ to $10.27 \%$ per year in the balance of system equipment and from $34.79 \%$ per year to $28.68 \%$ in the core high tech equipment.

The results from regressions 1-4 suggest that the US FDI has been an important determinant of imports of the balance of system equipment from both rich and poor countries, but more so for the emerging economies of China and India. The sector specific US FDI seems to explain the trend growth of exports in the balance of system equipment much more relative to that of the core hightech equipment for all countries, including China and India. ${ }^{25}$

Controlling for US FDI, GDP and the wind-solar electricity generation (regression column 6), we find that the trend growth in core high-tech equipment declines significantly from $9.95 \%$ per year to $4.8 \%$ per year for the rich countries and to a lesser extent for the poor countries from $13.03 \%$ to $11.24 \%$ per year comparing columns 5 and 6 . In the balance of system equipment, the trend growth rate of both the rich and the poor countries decline by about $20-21 \%$ after controlling for the three variables. For China, the trend growth declines substantially in both categories of equipment reducing from $24.76 \%$ per year to $14.58 \%$ per year for the balance of system equipment and from $28.59 \%$ per year to $13.94 \%$ per year for the core high-tech equipment. For India, however, after controlling for the three factors, the decline in trend growth rate is more pronounced in the balance of system equipment from $17.56 \%$ per year to $7.35 \%$ per year, and relatively less so in the core high-tech equipment from $34.78 \%$ per year to $25.24 \%$ per year.

\footnotetext{
${ }^{25}$ The trend growth rates estimation covering 22 countries for which we have complete data on FDI, GDP, and renewable power (regression 5) show the same pattern as before (regression 3) across rich and poor nations as well as China and India.
} 
The results from regression 5-6 indicate that for the rich countries as well as China, the trend growth in core high-tech products is halved after controlling, however, for India and other poor countries; the effect is not as pronounced for the core high-tech equipment exports.

From the above sets of regressions in Tables 3, three clear consistent results emerge concerning our hypotheses $\mathrm{H} 1, \mathrm{H} 2$ and $\mathrm{H} 3$ :

H1: Sector-specific US FDI is a significant factor in export growth of both rich and poor countries, but relatively more in the balance of system compared to the core equipment.

H2: Home market size has a positive effect on exports of high-tech power-generation equipment (although not always individually significant, it is jointly significant together with other control variables).

H3: Domestic wind-solar power sector has been a significant factor in the export of the core high-technology equipment to the US (more pronounced in rich countries and China).

We recognize that US FDI is unlikely to be randomly assigned across nation/year/industries and could be correlated with the error term in equation (1). ${ }^{26}$ Foreign investors will invest their scarce resources in those projects that yield a high risk adjusted rate of return. Recall that we lag US FDI one year in the regressions. While we do not believe that exports in year t cause US FDI in year $\mathrm{t}-1$ to grow, there could be omitted third factors causing both. If foreign investors believe that a developing nation's government will become actively involved in subsidizing green tech in the following year, then they may start to increase their FDI. Such complementarities between government policy and private capital are likely to help the industry to grow. In this case, our OLS estimates are likely to overstate the causal effects of US FDI because the coefficient on US FDI will partially reflect the unobserved increased effort by the exporting nation's government to promote

\footnotetext{
${ }^{26}$ Our renewable energy variable (as measured by electricity produced from wind/ solar/ biomass and geothermal) is less subject to concerns about endogeneity since it is determined by domestic electricity tariff policies, and climatechange mitigation measures for capacity installation in renewable energy production.
} 
green tech. ${ }^{27}$ In the absence of identifying a credible instrumental variable for US FDI by nation/year/industry category, we are cautious about giving our correlation estimates a causal interpretation. ${ }^{28}$ Future research should seek to study the likely synergies between export nation's renewables promotion policies and attracting FDI inflows.

It is relevant to note that the growth and maturity of the renewable energy industry in the developed countries (and more recent growth in developing countries) has been driven by government support policies. A study using patent applications as a proxy measure for technological innovations in a cross-section of OECD countries, established that public policies have indeed been significant in inducing innovations in renewable energy during the period 19782003 (Johnstone et al 2010). Thus, the inclusion of domestic renewable power generation as an explanatory variable in regression 6 to some extent controls for the effective renewable support policies enacted by the national governments.

\section{Conclusion}

The import of core-high tech wind and solar power generation equipment has grown faster than other high technology equipment in the US during the past two decades. The growth of imports from poorer countries have outpaced (though from far lower base) that from rich countries. China and India, in particular, have experienced phenomenally high export growth, with China exhibiting much higher trend growth in the balance of system equipment than India, and the latter exhibiting higher trend growth in the core high-tech equipment than China. Although richer countries like Germany, Japan, Denmark, Canada, continue to be major exporters of these high-tech equipment into the US, their import market shares (by value) have been eroded considerably.

\footnotetext{
${ }^{27}$ Moreover as we had observed earlier in section 2, high-tech exports from developing poor countries can also be driven by intermediate product imports (in the vertical global supply chain) facilitated by government policy towards processing trade, as well-documented for China and India (Koopman et al 2008, Goldberg et al 2010).

${ }^{28} \mathrm{We}$ have also estimated equation (1) and included nation/year fixed effects. In these regression results, that are available on request, we estimate a FDI elasticity of .46. By including nation/year fixed effects, the FDI coefficient is identified by within nation/year variation in FDI by the four FDI industry categories. This finding indicates that the FDI results cannot simply be a proxy for government macro energy policy because the nation/year fixed effects control for this.
} 
We find that sector-specific US FDI and country size are important correlates of exports to the US of the high-tech balance of system equipment from both rich and poor countries. However, these cannot explain much of the rapid growth in the core equipment exports to the US. For the core high-tech wind-solar equipment, we find that the home market effect in terms of wind-solar power generation played significant positive role for the rich nations as well as China. For the other poorer countries, including India, the home market effect of wind-solar power generation is also significant but not as pronounced.

Our analysis provides a stark comparison between countries, and the significance of overall macro trends in the export of renewable power generation equipment to the US. The rapid growth of exports from the emerging countries in the high-tech equipment and their share displacement of the rich industrialized countries in the US import market suggest that technology adoption in the relatively poor countries has been notably high over the last two decades. The unit of our analysis being the country-industry, we cannot distinguish whether multinational affiliates or domestic firms were the source of exports from the different countries; nor the extent of imported input embodied in the exports. ${ }^{29}$ However, given the overall nature of the products in our sample, from our results we can conclude that developing countries are rapidly emerging as the "green havens" producing technologically advanced renewable energy equipment.

Greater international trade and participation of Asian economies in renewable power equipment production has likely played a significant role in reducing the cost of such equipment. For example, the average solar PV module price has reduced from $\$ 4.66 / \mathrm{W}$ (per Watt) in 2004 to $\$ 2.01 / \mathrm{W}$ in 2010 , is expected to further drop to $\$ 1.49 / \mathrm{W}$ by 2015 . $^{30}$ Access to cheap imports from China has offered U.S consumers a great increase in consumer surplus (Weinstein and Broda 2008). In the

\footnotetext{
${ }^{29}$ Since intermediate inputs often fall within other product classification (like imports of silicon wafers used in solar cell manufacturing), country net import at the 10-digit HTS would not accurately reflect the embodied imported inputs. The value-added on imported inputs are best reflected at the plant-level export analysis.

30 "Global Solar PV Module Market - Downward Trend in Module Prices to Continue through 2015" http://www.marketresearch.com/
} 
case of renewables equipment, declines in these products' prices offer externality benefits. The role of international trade in mitigating environmental externalities merits future research.

While our study highlighted important role of FDI in the high-technology climate-mitigation industry for the developing countries, alternative means of technology access is increasingly evident within the industry. For instance, the firms from developing countries like China and India have engaged in acquisition of component-specialist firms in a bid to access technology, apart from licensing technology or entering into joint-ventures: the Indian wind turbine manufacturer Suzlon acquired Hansen Transmissions of Belgium (gearbox specialist) in 2006-07, and purchased RE Power of Germany (wind turbine manufacturer) in 2009, while the Chinese wind turbine manufacturer Goldwind acquired Vensys Energy of Germany (specialist in gearless wind turbines) in $2008 .^{31}$ Future research with firm-level data could attempt to explore this alternative channel of technology diffusion and its role in the growth of trade in the renewable energy industry.

\footnotetext{
${ }^{31}$ Goldwind began as a licensee of Vensys Energy in 2003.
} 


\section{References}

Alfaro, Laura and Andrew Charlton (2009) "Intra-Industry Foreign Direct Investment”, American Economic Review,

Barell, Ray and Nigel Pain (1997) "Foreign Direct Investment, Technological Change and Economic Growth within Europe”, The Economic Journal, Volume 107(445): 1770-1786.

Bhagwati, Jagdish N (1978). “Anatomy and Consequences of Exchange Control Regimes”, Studies in International Economic Relations, Volume 1, National Bureau of Economic Research.

Blomstrom, Magnus and Ari Kokko (1997) "How Foreign Investment Affects Host Countries", Policy Research Working Paper 1745, World Bank.

Bloom, Nicholas, Morko Draca and John Van Reenen (2011) “Trade Induced Technical Change? The Impact of Chinese Imports on Innovation, IT and Productivity", NBER Working Paper 16717, National Bureau of Economic Research.

Borensztein, E., J De Gregorio, and JW Lee (1998) "How does foreign direct investment affect economic growth?" Journal of International Economics, Volume 45: 115-135.

Copeland, B. and M. S. Taylor (2003) Trade, and the Environment, Theory and Evidence, Princeton University Press.

Copeland, B. and M. S. Taylor (2004), "Trade, growth and the environment," Journal of Economic Literature, Volume 42: 7-71.

Dechezleprete, Antoine, Matthieu Glachant and Yann Meniere (2009) “Technology transfer by CDM projects: a comparison of Brazil, China, India and Mexico”, Energy Policy, Volume 37(2): 703-711.

Driesen, David and David Popp (2010) “Innovating for Development: Meaningful Technology Transfer for Climate Disruption”, Journal of International Affairs, Volume 64(1):1-15.

Duke, R.D. and D.M. Kammen. "The Economics of Energy Market Transformation Initiatives," Energy Journal, 20 (4), 1999, pp. 15-64.

Falvey, Rodney E. (1981) “Commercial Policy and Intra-Industry Trade”, Journal of International Economics, Volume 11: 495-511.

Flam, Harry and Elhanan Helpman (1987) "Vertical Product Differentiation and North-South Trade", The American Economic Review, Volume 77 (5): 810-822.

Goldberg, Pinelopi K., Amit Khandelwal, Nina Pavcnik, and Petia Topalova (2010) "Imported Intermediate Inputs and Domestic Product Growth: Evidence from India" Quarterly Journal of Economics, Volume 125 (4): 1727-1767. 
Grossman, Gene M and Elhanan Helpman (1989) "Product Development and International Trade", The Journal of Political Economy, Volume 97 (6): 1261-1283.

Hanson, Gordon H. and Chong Xiang (2004) “The Home-Market Effect and Bilateral Trade Patterns", The American Economic Review, Volume 94 (4): 1108-1129.

Hummels, David, Jun Ishii and Kei-Mu Yi (2001) "The nature and growth of vertical specialization in world trade", Journal of International Economics, Volume 54 (1): 75-96.

Jacobson, Staffan and Volkmar Lauber (2006) "The politics and policy of energy system transformation - explaining the German diffusion of renewable energy technology”, Energy Policy, Volume 34: 256-76.

Johnstone, Nick, Ivan Hascic and David Popp (2010) "Renewable Energy Policies and Technological Innovation: Evidence based on Patent Counts", Environmental and Resource Economics, Volume 45(1): 133-155.

Keller, Wolfgang (2004) “International Technology Diffusion”, Journal of Economic Literature, Volume XLII: 752-782.

Koopman, Robert, Zhi Wang and Shang-Jin Wei (2008) "How Much of Chinese Exports is Really Made in China? Assessing domestic value-added when processing trade in pervasive", NBER Working Paper No. 14109, National Bureau of Economic Research.

Krugman 2008 “Trade and Wages, Reconsidered”, Brookings Papers on Economic Activity, Spring 2008: 103-154.

Krugman, Paul (1980) "Scale Economies, Product Differentiation, and the Pattern of Trade", The American Economic Review, Volume 70 (5): 950-959.

Krugman, Paul (1979) “A Model of Innovation, technology transfer, and the World Distribution of Income", The Journal of Political Economy, Volume 87 (2): 253-266.

Lesser, Jonathan (2010) “Gresham's Law of Green Energy”, Regulation, Winter 2010-2011 pages 12-18.

Lipsey, Robert E. (2004) "Home- and Host-Country Effects of Foreign Direct Investment”, in Robert E. Baldwin and L. Alan Winters ed. Challenges to Globalization: Analyzing the Economics, University of Chicago Press: 333-279.

Lipsey, Robert E. (2000) “Affiliates of US and Japanese Multinationals in Production and Trade" NBER-EASE Volume 9, Takatoshi Ito and Anne O. Krueger ed. The Role of Foreign Direct Investment in East Asian Economic Development: 147- 185.

OECD (2009) Financing Climate Change Mitigation: Towards A Framework for Measurement, Reporting and Verification, OECD and Environment Directorate International Energy Agency, COM/ENV/EPOC/IEA/SLT(2009)6. 
Pierce, Justin R. And Peter K. Schott (2009) “Concording U.S. Harmonized System Categories Over Time”, NBER Working Paper 14837, National Bureau of Economic Research.

Popp, David (2011) "International Technology Transfer, Climate Change, and the Clean Development Mechanism”, Review of Environmental Economics and Policy.

Popp, David, Richard G. Newell and Adam B. Jaffe (2009) "Energy, The Environment, and Technological Change”, NBER Working Paper 14832.

Posner, M.V. (1961) "International Trade and Technical Change”, Oxford Economic Papers, Volume 13 (3): 323-341.

REN21 (2010) Renewables 2010: Global Status Report, Renewable Energy Policy Network for the $21^{\text {st }}$ Century, Paris, REN21 Secretariat.

Rodrik, Dani (2006) “What's So Special About China's Exports?” NBER Working Paper 11947, National Bureau of Economic Research.

Saggi, Kamal (2002) “Trade, Foreign Direct Investment and International Technology Transfer: A Survey”, The World Bank Research Observer, Volume 17 (2): 191-235.

Schott, Peter K. (2008) “The relative sophistication of Chinese exports” Economic Policy: 5-49.

Schott, Peter K. (2004) “Across-Product Versus Within-Product Specialization in International Trade" The Quarterly Journal of Economics, MIT Press, Volume 119(2): 646-677.

UNCTAD (2010) World Investment Report 2010: Investing in a Low-Carbon Economy, United Nations Publication.

USITC (2005) "Renewable Energy Services: An Examination of US and Foreign Markets”, United States International Trade Commission, Publication \#3805.

USITC (2009) "Wind Turbines: Industry and Trade Summary”, United States International Trade Commission, Publication ITS-02.

Vernon, Raymond (1979) “The product cycle hypothesis in a new international environment", Bulletin: 255-267.

Vernon, Raymond (1966) "International Investment and International Trade in the Product Cycle", The Quarterly Journal of Economics, Volume 80 (2): 190-207.

Weinstein, David and Christian Broda (2008) "Exporting Deflation: Chinese Exports and Japanese Prices” Federal Reserve Bank of San Francisco Working paper, 2008-29.

Wind (2009) "HS Codes and the Renewable Energy Sector", International Centre for Trade and Sustainable Development, Geneva

WIPO (2009) Patent-based technology Analysis Report: Alternative Energy Technology, World Intellectual Property Organization. 
Wolak, Frank and Richard Morse (2010) China's Green Gift to the World, published in http://www.guardian.co.uk/commentisfree/cifamerica/2010/dec/30/coal-energy-industry

WTO (2011) Committee on Trade and Environment in Special Session: Report by the Chairman, 21 April, TN/TE/20, World Trade Organization.

Xing, Yuqing (2011) “China's High-tech Exports: Myth and Reality”, GRIPS Discussion Paper 1105, National Graduate Institute for Policy Studies, Tokyo, Japan.

Yu, James, Fuxing Ji, Ling Zhang and Yushou Chen (2009) “An over painted oriental arts: Evaluation of the development of the Chinese renewable energy market using the wind power market as a model” Energy Policy, Volume 37, Issue 12: 5221-25. 
Table 1. US imports of high-tech wind/solar electricity equipment (in million constant US\$, base 2000)

\begin{tabular}{|c|c|c|c|c|c|}
\hline Category of renewable energy equipment & 1989 & 1995 & 2000 & 2005 & 2010 \\
\hline Core high-tech wind/solar equipment & 280 & 160 & 313 & 1250 & 4200 \\
\hline Balance of system equipment & 514 & 2540 & 3130 & 3800 & 5210 \\
\hline Total US import value of 27 wind and solar equipment & 794 & 2700 & 3443 & 5050 & 9410 \\
\hline
\end{tabular}

Core high technology equipment includes obsolete HS codes after concordance. ${ }^{32}$

Table 2. Country Shares in US Imports (by value) of High-Tech Core Wind and Solar Equipment in 1989 and 2010

\begin{tabular}{|c|c|c|c|c|c|c|c|c|c|c|}
\hline \multirow[t]{2}{*}{ Country } & \multicolumn{2}{|c|}{ Blades } & \multicolumn{2}{|c|}{ Wind Turbines } & \multicolumn{2}{|c|}{ Hub, Drive \& parts } & \multicolumn{2}{|c|}{ Solar Modules } & \multicolumn{2}{|c|}{ Solar Cells } \\
\hline & $\underline{1989}$ & $\underline{2010}$ & $\underline{1989}$ & $\underline{2010}$ & $\underline{1989}$ & $\underline{2010}$ & $\underline{1989}$ & $\underline{2010}$ & $\underline{1989}$ & $\underline{2010}$ \\
\hline Australia & $\overline{0.14}$ & $\overline{0.02}$ & 0 & $\overline{0.01}$ & 0 & $\overline{1.05}$ & 3 & 0 & $\overline{17.8}$ & $\overline{0.04}$ \\
\hline Brazil & 0.39 & 16 & 0 & 0.13 & 3.11 & 0.86 & 0 & 0 & 3.23 & 0 \\
\hline Canada & 11.12 & 8.02 & 4.51 & 0.61 & 39.6 & 14.3 & 0.19 & 0.05 & 0.56 & 0.03 \\
\hline China & 0.7 & 10.46 & 0.3 & 0.59 & 0.77 & 17.58 & 0.11 & 49.72 & 0 & 15.49 \\
\hline Denmark & 1.04 & 10.04 & 9.19 & 66.77 & 5.97 & 2.31 & 0 & 0.01 & 0 & 0 \\
\hline France & 1.1 & 2.1 & 3.97 & 0.03 & 4.28 & 1.23 & 0 & 0 & 0.15 & 0 \\
\hline Germany & 34.29 & 11.68 & 5.53 & 4.41 & 15.36 & 8.38 & 0 & 1.65 & 6.13 & 19.07 \\
\hline Hong Kong & 0.01 & 0.1 & 0 & 0 & 0.37 & 0.05 & 2.79 & 0.03 & 0.56 & 0 \\
\hline India & 0 & 11.22 & 0 & 11.79 & 0 & 1.24 & 0 & 1.29 & 0 & 0.09 \\
\hline Indonesia & 0.00 & 0.00 & 0.00 & 0.00 & 0.00 & 0.31 & 0.00 & 0.00 & 0.00 & 0.00 \\
\hline Italy & 2.33 & 0.73 & 0 & 7.35 & 0.53 & 1.6 & 0.04 & 0.02 & 0.18 & 0.01 \\
\hline Japan & 8.74 & 2.82 & 16.07 & 0.02 & 15.82 & 8.91 & 48.58 & 10.3 & 24.03 & 2.46 \\
\hline Korea, South & 0.08 & 1.2 & 0 & 0.68 & 0.23 & 2.01 & 0 & 0.6 & 0 & 3.32 \\
\hline Malaysia & 0 & 0.01 & 0 & 0 & 0.06 & 0.01 & 0 & 6 & 29.85 & 0.04 \\
\hline Mexico & 0.11 & 11.32 & 0.02 & 0 & 3.05 & 25.49 & 37.51 & 20.74 & 12.87 & 0.46 \\
\hline Netherlands & 3.01 & 0.86 & 0.21 & 0.07 & 0.13 & 1.59 & 0 & 0.16 & 0 & 0.01 \\
\hline Philippines & 0 & 0.11 & 0 & 0 & 0.57 & 0 & 0 & 1.2 & 0 & 0.09 \\
\hline Singapore & 4.99 & 0.35 & 0 & 0 & 0.63 & 0.35 & 0.11 & 0.05 & 2.83 & 27.31 \\
\hline Spain & 0.41 & 6.82 & 0.02 & 7.12 & 0.01 & 2.58 & 0 & 0.11 & 0 & 0.09 \\
\hline Sweden & 2.88 & 0.19 & 16.18 & 0 & 0.81 & 0.07 & 0 & 0.66 & 0.05 & 0.36 \\
\hline Switzerland & 0.71 & 0.19 & 41.98 & 0 & 4.63 & 0.37 & 0 & 0.05 & 0.02 & 0.02 \\
\hline Taiwan & 2.15 & 0.21 & 0.02 & 0.02 & 0.3 & 1.81 & 1.98 & 7.25 & 1.15 & 29.43 \\
\hline Thailand & 0 & 0.02 & 0 & 0 & 0 & 0.33 & 0 & 0 & 0 & 0 \\
\hline United Kingdom & 19.29 & 3.09 & 1.98 & 0.11 & 2.77 & 2.98 & 4.76 & 0.02 & 0.33 & 0.19 \\
\hline Total U.S Share for the 24 countries & 93.49 & 97.56 & 99.98 & 99.71 & 99 & 95.4 & 99.07 & 99.91 & 99.74 & 98.51 \\
\hline
\end{tabular}

\footnotetext{
${ }^{32}$ Since several HTS codes have changed during the period of analysis here, we use the concordance between obsolete and new codes for continuity. See the data appendix
} for details. 
Table 3. $\log \left(\right.$ Import $\left._{\mathrm{US}}\right)$ regressions with country fixed-effects

\begin{tabular}{|c|c|c|c|c|c|c|}
\hline & 1 & 2 & 3 & 4 & 5 & 6 \\
\hline \multirow[t]{2}{*}{ Trend } & $0.0556 * * *$ & $0.0320 * * *$ & $0.0558 * * *$ & $0.0456 * * *$ & $0.0612 * * *$ & $0.0480 * * *$ \\
\hline & {$[0.0049]$} & {$[0.0085]$} & {$[0.0049]$} & {$[0.0094]$} & {$[0.0048]$} & {$[0.0118]$} \\
\hline \multirow[t]{2}{*}{ Trend*Core } & $0.0470 * * *$ & $0.0418 * * *$ & $0.0464 * * *$ & $0.0423 * * *$ & $0.0383 * * *$ & 0.0083 \\
\hline & {$[0.0117]$} & {$[0.0118]$} & {$[0.0115]$} & {$[0.0117]$} & {$[0.0125]$} & {$[0.0120]$} \\
\hline \multirow[t]{2}{*}{ Trend $*$ Poor } & $0.0432 * * *$ & $0.0206^{*}$ & $0.0181 *$ & $0.0235 * *$ & $0.0308 * *$ & $0.0255^{*}$ \\
\hline & {$[0.0096]$} & {$[0.0117]$} & {$[0.0097]$} & {$[0.0120]$} & {$[0.0128]$} & {$[0.0137]$} \\
\hline \multirow[t]{2}{*}{ Trend* Poor*Core } & 0.0184 & 0.0152 & 0.0079 & 0.0038 & 0.0162 & $0.0306^{* *}$ \\
\hline & {$[0.0114]$} & {$[0.0115]$} & {$[0.0123]$} & {$[0.0125]$} & [0.0159] & {$[0.0154]$} \\
\hline \multirow[t]{2}{*}{ Trend*China } & & & $0.1736^{* * *}$ & $0.0892 * * *$ & $0.1556^{* * *}$ & $0.0723 * *$ \\
\hline & & & {$[0.0125]$} & {$[0.0223]$} & {$[0.0180]$} & {$[0.0340]$} \\
\hline \multirow[t]{2}{*}{ Trend*China*Core } & & & -0.0155 & -0.0155 & -0.0361 & $-0.0453^{* *}$ \\
\hline & & & [0.0198] & {$[0.0207]$} & {$[0.0238]$} & {$[0.0226]$} \\
\hline \multirow[t]{2}{*}{ Trend*India } & & & $0.0927 * * *$ & $0.0336^{*}$ & $0.0836^{* * *}$ & 0.0231 \\
\hline & & & {$[0.0144]$} & {$[0.0188]$} & {$[0.0176]$} & [0.0239] \\
\hline \multirow[t]{2}{*}{ Trend*India*Core } & & & $0.1270 * * *$ & $0.1380 * * *$ & $0.1179 * * *$ & $0.1169 * * *$ \\
\hline & & & {$[0.0166]$} & {$[0.0167]$} & {$[0.0209]$} & {$[0.0199]$} \\
\hline \multirow[t]{2}{*}{$\log (\mathrm{FDI})$} & & $0.3793^{* * *}$ & & $0.3662 * * *$ & & $0.2982 * * *$ \\
\hline & & {$[0.0365]$} & & {$[0.0374]$} & & {$[0.0459]$} \\
\hline \multirow[t]{2}{*}{$\log (\mathrm{GDP})$} & & $0.8019 * * *$ & & 0.2013 & & 0.4041 \\
\hline & & {$[0.2856]$} & & {$[0.3533]$} & & {$[0.4897]$} \\
\hline \multirow[t]{2}{*}{$\log ($ RenewElec $) *$ Core } & & & & & & $0.1971 * * *$ \\
\hline & & & & & & {$[0.0289]$} \\
\hline \multirow[t]{2}{*}{ Dummy $_{c}$} & $-0.7873 * * *$ & $-0.6481 * * *$ & $-0.7768 * * *$ & $-0.6570 * * *$ & $-0.5589 * * *$ & $-4.5548 * * *$ \\
\hline & {$[0.1440]$} & {$[0.1453]$} & {$[0.1412]$} & {$[0.1442]$} & {$[0.1547]$} & {$[0.6408]$} \\
\hline \multirow[t]{2}{*}{ Dummy $_{m}$} & $0.1520 * * *$ & 0.0255 & $0.1460 * * *$ & 0.0291 & -0.0188 & $-0.0802 * *$ \\
\hline & {$[0.0437]$} & {$[0.0383]$} & {$[0.0434]$} & {$[0.0384]$} & {$[0.0440]$} & {$[0.0397]$} \\
\hline \multirow[t]{2}{*}{ Constant } & $12.0499 * * *$ & -0.2128 & $12.0507 * * *$ & $7.5386^{*}$ & $12.5415^{* * *}$ & 5.6306 \\
\hline & {$[0.1274]$} & {$[3.5965]$} & {$[0.1238]$} & [4.4923] & {$[0.1314]$} & [6.3391] \\
\hline Observations & 9155 & 9155 & 9155 & 9155 & 7744 & 7744 \\
\hline R-squared & 0.2584 & 0.2821 & 0.2675 & 0.2862 & 0.2674 & 0.2834 \\
\hline
\end{tabular}

The omitted category is the balance of system equipment in relatively rich countries (i.e. countries with greater than median GDP per capita in constant US\$). Core high technology products include - blades, hub, wind turbines, solar modules and solar cells. Balance of system products include - towers, speed changers, gears, clutches, generators, rectifiers, inverters and anemometers

Figures in parentheses give the standard errors of the estimated coefficients. *** indicates significant at $1 \%$, ** significant at $5 \%, *$ significant at $10 \%$. The standard errors are clustered by country/year. 


\section{Data Appendix}

Data source: We have built the data from four sources. The data on US imports is taken from Robert Feenstra's trade database (1989-2006), supplemented with data directly from the USITC online database for years 2007 through 2010. The FDI data is taken from US Bureau of Economic Analysis. Country-specific data on GDP, and electricity from renewable sources, are from the World Bank database. Price indices have been taken for deflation of import data taken from US Bureau of Labour Statistics.

Commodity trade data: We use general imports (i.e. imports as they come off the dock in the US) reported in US\$, and convert these to constant US 2000\$ using the US Import Price Index for all commodities except petroleum (year 2000=100). The 10-digit HTS classification has been revised several times over the time-period of our analysis, and some of our high-tech core products have different codes over time. To address this, we have used the concordance of old obsolete HTS codes with new HTS codes from Pierce and Schott (2009). For example, code 8502300000 for "other generator sets" included wind-powered generators until 1995, but since 1996 a new code of 8502310000 was adopted exclusively for "windpowered generators". The details of the obsolete codes for each of the 27 products are listed in Table A1 at the end.

US FDI data: USBEA data by country by industry (by SIC classification for 1988-98 and by NAICS classification 1999-2009) for the 22 year period 1988-2009. The data in million US dollars is converted to constant US $2000 \$$ million using the Export Price Index.

Country-specific factors (World Bank database and IMF):

GDP per capita and GDP: The gross domestic product per capita and GDP (both at constant 2000 US \$) are taken from the World Bank database. However, since the data for Taiwan is not available in the World Bank database, we have used the IMF database in for the current US dollar values of these variables. Using Taiwan's GDP deflator (IMF database) we compute the constant US\$ values of annual GDP and GDP per capita (base year 2000).

RenewElec: We calculate the annual electricity production from wind, solar, geothermal, and biomass sources of each country as the residual of the total electricity production less electricity generated from coal, hydro, oil, and natural gas.

Our final data panel is unbalanced with missing data on sector-specific US FDI, as well as electricity from renewable sources. According to the US BEA, some of the US FDI data by country and industry level are withheld to avoid disclosure of data of certain companies. For Taiwan we do not have data on renewable energy, while for Singapore electricity generated from wind/ solar/ biomass/ geothermal is zero.

Table 4. Summary Statistics

\begin{tabular}{llllll}
\hline Variable & Obs & Mean & Std. Dev. & Min & Max \\
\hline Log(Import) & 9155 & 13.34421 & 2.681616 & 7.040245 & 20.75951 \\
Log(FDI) & 9428 & 6.392317 & 1.498658 & -0.157 & 9.522493 \\
Log(GDP) & 9428 & 13.17078 & 1.046298 & 10.56402 & 15.4644 \\
Log(RenewElec) & 7957 & 22.02226 & 2.212534 & 13.81551 & 25.38671 \\
\hline
\end{tabular}


Table A1. 10-digit HTS Codes of Wind and Solar Energy Equipment

\begin{tabular}{|c|c|c|c|c|c|}
\hline & HTS 10-digit & Obsolete HS Codes & HTS Code Description & Component & FDI Category \\
\hline 1 & 7308200000 & & Tower and lattice masts of iron and steel & Tower & 1 (Primary \& fabricated metal- NAICS 331, 332) \\
\hline 2 & 8412909080 & & Parts of engines and motors, nesoi & Blades & 2 (Machine manufacturing - NAICS 333) \\
\hline 3 & 8483405010 & & Fixed ratio speed changers & Gearbox & 2 (Machine manufacturing - NAICS 333) \\
\hline 4 & 8483405050 & & Multiple and variable ratio speed changers & Gearbox & 2 (Machine manufacturing - NAICS 333) \\
\hline 5 & 8483407000 & & Speed changers, nesoi & Gearbox & 2 (Machine manufacturing - NAICS 333) \\
\hline 6 & 8483408000 & & Ball and roller screws & Gearbox & 2 (Machine manufacturing - NAICS 333) \\
\hline 7 & 8483409000 & & Gears, except transmission elements & Gearbox & 2 (Machine manufacturing - NAICS 333) \\
\hline 8 & 8483604040 & 84836040000 (until 2000) & Clutches and universal joints, clutches & Coupling, shafts & 2 (Machine manufacturing - NAICS 333) \\
\hline 9 & 8483604080 & 84836040000 (until 2000) & Clutches and universal joints, univ. joints & Coupling, shafts & 2 (Machine manufacturing - NAICS 333) \\
\hline 10 & 8483608000 & & Shaft couplings, except universal joints & Coupling, shafts & 2 (Machine manufacturing - NAICS 333) \\
\hline 11 & 8501610000 & & AC generators, power output $\leq 75 \mathrm{KVA}$ & Generator & 3 (Electrical equipment - NAICS 335) \\
\hline 12 & 8501620000 & & AC generators, $>75$ but $\leq 375 \mathrm{KVA}$ & Generator & 3 (Electrical equipment - NAICS 335) \\
\hline 13 & 8501630000 & & AC generators, $>375$ but $\leq 750 \mathrm{KVA}$ & Generator & 3 (Electrical equipment - NAICS 335) \\
\hline 14 & 8501640020 & & AC generators, $>750$ but $\leq 1000 \mathrm{KVA}$ & Generator & 3 (Electrical equipment - NAICS 335) \\
\hline 15 & 8501640030 & & AC generators, $>1000$ but $\leq 4000 \mathrm{KVA}$ & Generator & 3 (Electrical equipment - NAICS 335) \\
\hline 16 & 8501640050 & & AC generators, $>4000 \mathrm{KVA}$ output & Generator & 3 (Electrical equipment - NAICS 335) \\
\hline 17 & 8502310000 & 8502300000 (till 1995) & Other generating sets, wind powered & Wind Generator & 3 (Electrical equipment - NAICS 335) \\
\hline 18 & 8503009545 & $\begin{array}{l}8503006040 \text { (until 1993), } \\
8503008540 \text { (1994) }\end{array}$ & Parts of generators, other than commutators & Hub, drive, parts & 3 (Electrical equipment - NAICS 335) \\
\hline 19 & 8504409510 & \multirow{6}{*}{$\begin{array}{l}\text { (until 1996) 8504408004, } \\
8504408008,8504408010, \\
8504408015,8504408025, \\
8504408040,8504408060, \\
8504409001,8504409007, \\
8504409012,8504409018, \\
8504409025,8504409040, \\
8504409060\end{array}$} & Power supplies (rectifier), output $<50 \mathrm{~W}$ & Rectifier & 4 (Computer \& electronic products -NAICS 334) \\
\hline 20 & 8504409520 & & Power supplies (rectifier), $>50 \mathrm{~W}$ but $<150 \mathrm{~W}$ & Rectifier & 4 (Computer \& electronic products -NAICS 334) \\
\hline 21 & 8504409530 & & Power supplies (rectifier), $>150 \mathrm{~W}$ but $<500 \mathrm{~W}$ & Rectifier & 4 (Computer \& electronic products -NAICS 334) \\
\hline 22 & 8504409540 & & Power supplies (rectifier), $>500 \mathrm{~W}$ & Rectifier & 4 (Computer \& electronic products -NAICS 334) \\
\hline 23 & 8504409570 & & Inverters (static converters) & Inverter & 4 (Computer \& electronic products -NAICS 334) \\
\hline 24 & 8504409580 & & Inverters (static converters), nesoi & Inverter & 4 (Computer \& electronic products -NAICS 334) \\
\hline 25 & 8541406020 & & Solar cells, assembled into modules or panels & PV panel/module & 4 (Computer \& electronic products -NAICS 334) \\
\hline 26 & 8541406030 & & Solar cells, not made into panels or modules & PV cells & 4 (Computer \& electronic products -NAICS 334) \\
\hline 27 & 9026804000 & & Heat meters and anemometers & Anemometer & 4 (Computer \& electronic products -NAICS 334) \\
\hline
\end{tabular}

Source: Based on HTS code identified for renewable energy equipment in USITC (2005) and USITC (2009), and Wind (2007). 